\title{
Renal function impairment in Hypothyroidism
}

\author{
HS Chaudhury ${ }^{1}$, KK Raihan ${ }^{2}$, MN Uddin ${ }^{3}$, SM Ansari ${ }^{4}$ \\ M Hasan ${ }^{2}$, M Ahmed ${ }^{5}$, MF Kabir ${ }^{2}$, MZ Hoque ${ }^{6}$ \\ ${ }^{1}$ Dept of Biochemistry, International Medical College, Tongi, Gazipur, Bangladesh \\ ${ }^{2}$ Institute of Nuclear Medicine and Ultrasound, Dhaka, Bangladesh \\ ${ }^{3}$ Dept of Clinical Biochemistry, National Institute of Cardiovascular Diseases, Dhaka \\ ${ }^{4}$ Centre for Nuclear Medicine and Ultrasound, Bogra, Bangladesh \\ ${ }^{5}$ Dept of Microbiology, Tairunnessa Medical College, Tongi, Gazipur \\ ${ }^{6}$ Dept of Pathology, University of Malaysia Sabah, Sabah, Malaysia
}

\begin{abstract}
Background: Hypothyroidism is an important public health problem in Bangladesh. It is associated with increased risk for atherosclerosis and other complications. The frank development of hypothyroidism is associated with metabolic derangements including dyslipidemia- which is an etiopathologic factor for development of renal impairment. This study was to evaluate whether hypothyroidism is associated with impaired renal function. Methods: Using a cross sectional analytical study design, a total of 111 subjects attending Out Patient Department, Center for Nuclear Medicine and Ultrasound, Bogra Medical College during January 2007 to December 2007 were included purposively. Eighty newly diagnosed hypothyroid patients (Group I) and 31 healthy adults (Group II) were enrolled in this study. Serum thyroid stimulating hormone and serum free thyroxine were assayed by radioimmunoassay. Serum fasting lipid profile, serum creatinine and serum uric acid were estimated by enzymatic colorimetric method. Estimated GFR was calculated using MDRD equation. Results: The mean $( \pm S D)$ age of in Group I and Group II were 35.59 $( \pm 6.91)$ and $37.35( \pm 2.78)$ years and were comparable. In Group I, there were 66 females and 14 males. In Group II, there were 16 females and 15 males. The mean BMI was $25.49 \pm 2.17 \mathrm{~kg} / \mathrm{m} 2$ in Group I and $24.24 \pm 1.99 \mathrm{~kg} / \mathrm{m} 2$ in Group II. The mean $( \pm \mathrm{SD})$ Serum total-cholesterol, LDL- cholesterol and tryacylglycerol in Group I were significantly higher than that in Group II. Serum HDL cholesterol in Group I was significantly lower than that in Group II $(p<0.001)$. The mean $( \pm S D)$ serum creatinine was significantly higher in Group I than Group II $(\mathrm{P}<0.001)$. The estimated glomerular filtration rate (eGFR) was lower in Group I compared to Group II $(p=0.011)$. In Group I (Hypothyroid), there were significant correlations of BMI, S Total-Cholesterol, S HDLCholesterol, S LDL-Cholesterol, $\mathrm{S}$ triglycerides and $\mathrm{S}$ creatinine with serum TSH level. In Group I (Hypothyroid), there were significant positive correlations of BMI and TSH with serum creatinine. Conclusions: Hypothyroidism is associated with dyslipidemia, hyperuricemia and impaired renal function. Therefore, patients presenting with these biochemical abnormalities are recommended to be investigated for hypothyroidism and vice versa.
\end{abstract}

Key words : Renal function and Hypothyroidism 


\section{Introduction}

Hypothyroidism due to iodine deficiency is a serious global public health problem, especially in southeast Asia. Iodine deficiency disorders (IDD) is endemic in Bangladesh, Bhutan, India, Indonesia, Myanmar, Nepal, and Thailand. The recent survey conducted in Bangladesh in 2004 showed that the prevalence of goiter was 6.2$11.7 \%$ in women and children. Cretinism was prevalent among $0.5 \%$ overall. The prevalence iodine deficiency, as assessed by urinary iodine excretion $<100 \mu \mathrm{g} / \mathrm{dl}$, was $33.8-38.6 \%$ [1].

The association between thyroid dysfunction and dyslipidemia was first reported in 1930 [2]. Since then there were studies on the relationships between thyroid function, lipid status, and cardiovascular outcomes. However the relationship still remains incompletely understood. A review of the relationship between hypothyroidism and dyslipidemia describes the prevalence of thyroid dysfunction and the lipid effects of overt hypothyroidism [3].

Certain effects of the hypothyroid state on the kidney are well established. Histological changes have been demonstrated in both rats and humans. Physiological effects include changes in water and electrolyte metabolism, notably hyponatremia, and reliable alterations of renal hemodynamics, including decrements in renal blood flow, renal plasma flow, glomerular filtration rate (GFR), and single nephron GFR. In one study GFR failed to reach the levels seen in euthyroid controls following the initiation of thyroid hormone replacement therapy, leaving open the possibility that the effect was not fully reversible. The cause of the decreased renal plasma flow and GFR observed is believed to be principally due to the generalized hypodynamic state of the circulatory system in hypothyroidism [4]. They recently cared for a patient who developed a serum creatinine level of 159 ?mol/L (1.8 mg/dL; normal range, 35- 124 ?mol/L [0.4-1.4 mg/dL]) associated with normal findings on urinalysis during acute, severe iatrogenic hypothyroidism following levothyroxine sodium treatment withdrawal as part of thier protocol for treatment of thyroid carcinoma. The patient had had a normal serum creatinine level of $97 ? \mathrm{~mol} / \mathrm{L}(1.1 \mathrm{mg} / \mathrm{dL})$ while in the euthyroid state at the time of thyroidectomy, and his creatinine level returned to this same level when a euthyroid state was reachieved following re-initiation of levothyroxine after treatment. This led them to suspect hypothyroidism as the cause of his elevated creatinine level, and prompted them to conduct an analysis of there patients treated in this manner to assess for similar changes, and to determine whether these changes were consistent or sporadic, and if they were fully reversible [4].

One of the important, and mostly overlooked, manifestations of hypothyroidism is the impairment of renal function. In a report of 41 patients with primary hypothyroidism, creatinine clearance $(\mathrm{CrCl})$ was found to be slightly reduced in all patients, and $54 \%$ showed a mild increase in serum creatinine ( $\mathrm{SCr}$ ) ranging from 106 to $186 \mathrm{~m} \mathrm{~mol} / \mathrm{L}(1.2-2.1 \mathrm{mg} / \mathrm{dL})$. In hypothyroidism, renal blood flow rate, glomerular filtration rate (GFR), and tubular reabsorptive and secretory capacities are all reduced. Although the blood urea nitrogen (BUN) level is usually normal, $\mathrm{SCr}$ and uric acid levels may be increased [5].

The association between hypothyroidism and hyperuricemia was first suggested in use examined 520 patients suffering from gout and found hypothyroidism in $20 \%$ of the males and in $30 \%$ of the females. Subsequent studies confirmed this association, furthermore suggesting that hypothyroid hyperuricemia could be due to a decrease in both the renal plasma flow and urate excretion [6].

In the above perspective of dyslipidimia and impaired renal function in the setting of hypothyrodisim, it is very important to characterize the dyslipidimia and impaired renal function in our hypothyroid patients.

In Bangladesh, a study was done in Dhaka area, to see the relationship of dyslipidimia and 
impaired renal function of hyothyroidism patients [7]. However no study was done in northern part of Bangladesh. The number of hypothyroid patients in North Bengal is relative high. It is endemic in some areas like Sirajganj, Bogra, Gaibandha and Jaipurhat. To address the problem in a more comprehensive way we need to characterize dyslipidimia and impaired renal function in hypothyroid population of northern part of our country. An attempt has been in this study to find out the relationship between dyslipidimia and impaired renal function with hypothyroidism in this population. Research hypothesis was hypothyroidism is associated impaired renal function. The objective of this study was to evaluate whether hypothyroidism is associated with impaired renal function.

\section{Subjects And Methods}

Using a cross sectional analytical study design, a total of 111 subjects attending Out Patient department of Center for Nuclear Medicine and Ultrasound, Mohammed Ali Hospital Campus, Bogra during January 2007 to December 2007 were purposively included in the study. Eighty subjects were newly diagnosed hypothyroid subjects in Group I and thirty one were euthyroid subjects in group II taken as control.

Inclusion criteria: 1) Patients who fulfill selection criteria were included in this study. 2) Adult patients age between 20-60 years of either sex. 3) Patients who did not received supplementations with thyroid hormone. 4) Patients who did not received supplementations with lipid lowering medication.

Exclusion criteria: 1) Patients with history of underlying disease. 2) Chronic renal failure (CRF). 3) Liver disease. 4) Pregnancy, 5) Hypertension (HTN), 6) Age under 20 years with hypothyroidism, 6) Patients with history of diabetes mellitus.

Data were collected by interviewer administered structured questionnaire. The variables included were age, sex, BMI and symptoms of hypothyroidism. Clinical history and symptoms

HS Chaudhury, KK Raihan, MN Uddin, SM Ansari et al

of hypothyrodism were diagnosed in each subjects. If the symptoms of hypothyroid are present then the study subjects sent for investigation of TSH and FT4 level. Next day was fasting sample was collected for Serum total-cholesterol, HDL- cholesterol, LDLcholesterol, triacylglycerol and serum creatinine. The other variables recorded included measurements of height and weight. The weighing tools were calibrated daily by known standard weight and height. The subject stood in an erect posture vertically with the occiput, back, hip and heal touching the wall behind.

Serum TSH, FT4 level were measured by Immunoradiometric assay. HDL cholesterol, Serum total cholesterol and Triglycerides were measured by enzymatic colorimetric method and LDL cholesterol calculated by Friedewald's Formula. Estimated glomerular filtration rate (eGFR) was calculated using the following equation developed by the Modification of Diet in Renal Disease (MDRD) Study: eGFR = $186.3 \times \mathrm{S}$ creatinine $(\mathrm{mg} / \mathrm{dl})-1.154 \times$ age- 0.203 [for female x 0.74].

Statistical analysis: The means of quantitative variables (e.g age, BMI etc) between the two groups were compared by student's t test, association of qualitative variables (e.g sex) with presence or absence of hypothyroidism were test by 2 test. Correlation of different quantitative variable with serum FT4, TSH and serum createnine were estimated by correlation coefficient (r) in Group I and Group II separately. All statistical tests were considered significant at a level of $p$ value $<0.05$. All data analyzed by using Computer Software SPSS (Statistical Packages for Social Science) version 10.0.

Ethical Issues: The study was approved by the Academic Committee of the Institute of Nuclear Medicine and Ultrasound, BSMMU campus Dhaka. The objectives and procedure were explained in detail to the subjects. Written informed consent was obtained from each subject. 
Renal function impairment in Hypothyroidism

\section{Results}

Clinical characteristics of the study subjects are shown in Table I. The mean BMI in Group I was higher than that of Group II $(\mathrm{p}=0.006)$. Group I contained more females $66(82.5 \%)$ than that in Group II $16(51.6 \%)$. The mean $( \pm S D)$ serum TSH in Group I (70.66 $\pm 24.73 \mathrm{mIU} / \mathrm{L})$ was significantly higher than that in Group II (2.99 $\pm 1.43 \mathrm{mIU} / \mathrm{L}$ ), $\mathrm{p}<0.001$, (Table II). The median (range) Free T4 in Group I (4.6 (0.3 - 8.3) $\mathrm{pmol} / \mathrm{L})$ was lower than that in Group II (15.5 (1.71 -180.10) pmol/L), $\mathrm{p}<0.001$ (Table II).

Table I: Characteristics of the study subjects

\begin{tabular}{|c|c|c|c|c|}
\hline \multirow[t]{3}{*}{ Variables } & \multirow{2}{*}{\multicolumn{2}{|c|}{ 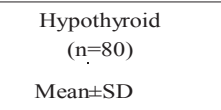 }} & \multirow{2}{*}{\multicolumn{2}{|c|}{$\begin{array}{c}\text { Euthyroid } \\
\quad(\mathrm{n}=31) \\
\text { Mean } \pm \mathrm{SD}\end{array}$}} \\
\hline & & & & \\
\hline & $\mathrm{N}$ & $\%$ & $\mathrm{n}$ & $\%$ \\
\hline Age in years & \multicolumn{2}{|c|}{$35.59 \pm 6.91$} & \multicolumn{2}{|c|}{$37.35 \pm 2.78$} \\
\hline $20-29$ & 17 & $(21.3 \%)$ & 10 & $(32.3 \%)$ \\
\hline $30-39$ & 33 & $(41.3 \%)$ & 15 & $(48.4 \%)$ \\
\hline $40-49$ & 30 & $(37.5 \%)$ & 6 & $(19.4 \%)$ \\
\hline \multicolumn{5}{|l|}{ Sex } \\
\hline Male & 14 & $(17.5 \%)$ & 15 & $(48.4 \%)$ \\
\hline Female & 66 & $(82.5 \%)$ & 16 & $(51.6 \%)$ \\
\hline
\end{tabular}

Table II: Thyroid function status of the study subjects

\begin{tabular}{lccc}
\hline & Group I & Group II \\
Variables & $\begin{array}{c}\text { Hypothyroid } \\
(\mathrm{n}=80)\end{array}$ & $\begin{array}{c}\text { Euthyroid } \\
(\mathrm{n}=31)\end{array}$ & \\
& \multicolumn{4}{c}{\begin{tabular}{l} 
Mean $\pm \mathrm{SD} /$ Median (Range) \\
\multicolumn{4}{c}{ Mean \pm SD/Median (Range) }
\end{tabular}} \\
\hline $\begin{array}{l}\text { Serum TSH } \\
(\mathrm{mIU} / \mathrm{L})\end{array}$ & $70.66 \pm 24.73$ & $2.99 \pm 1.43$ & $0.001 "$ \\
Serum Free T4 & $4.6(0.3-8.3)$ & $15.5(1.71-180.10)$ & $0.001 "$ \\
\hline
\end{tabular}

a Using student $t$ test

b Using Mann Whitney U test

$\mathrm{TSH}=$ Thyroid stimulating hormone, $\mathrm{T} 4=$ Thyroxine

The mean $( \pm S D)$ Serum total cholesterol $(\mathrm{mg} / \mathrm{dl})$ in Group I $(235.3 \pm 47.92)$ was significantly higher than that in Group II (143.8 $\pm 15.03, p<0.001$, Table III). The mean $( \pm S D)$ Serum HDL cholesterol $(\mathrm{mg} / \mathrm{dl})$ in Group I
$(44.48 \pm 9.2)$ was significantly higher than that in Group II $(49.35 \pm 4.08, p<0.001)$. The mean $( \pm \mathrm{SD})$ Serum LDL cholesterol $(\mathrm{mg} / \mathrm{dl})$ in Group I (139.7 \pm 45.55$)$ was significantly higher than that in Group II $(86.29 \pm 13.76$, $\mathrm{p}<0.001)$. The median range triacylglycerol $(\mathrm{mg} / \mathrm{dl})$ in Group I was 200.0 (110 - 320) was significantly higher than that in Group II 120.0 $(60-130, p<0.001)$. The mean $( \pm S D)$ serum creatinine was $1.447( \pm 0.34) \mathrm{mg} / \mathrm{dl}$ in Group I and $1.026( \pm 0.2) \mathrm{mg} / \mathrm{dl}$ in Group II (Table IV). The mean serum creatinine was higher Group I than that of Group II $(p=0.001)$. Among the male the mean $( \pm S D)$ serum creatinine level was higher in Group I $(1.46 \pm 0.30)$ than that of Group II $(0.98 \pm 0.09, \mathrm{p}<0.001)$. Among the female the mean $( \pm S D)$ serum creatinine level was higher in Group I $(1.36 \pm 0.49)$ than that of Group II $(1.08 \pm 0.26, p>0.064)$. The mean $( \pm \mathrm{SD})$ estimated glomerular filtration rate (eGFR, $\mathrm{ml} / \mathrm{min} / 1.73 \mathrm{~m} 2$ ) was lower in Group I $(70.3 \pm 14.2)$ compared to Group II $(98.9 \pm 18.5, p=0.011$, Table IV). Among the male the mean $( \pm S D)$ uric acid level was higher in Group I $(5.854 \pm 1.27)$ than that of Group II $(5.08 \pm 0.67, \mathrm{p}<0.050)$. Among the female the mean $( \pm \mathrm{SD})$ uric acid level was higher in Group I $(6.17 \pm 1.48)$ than that of Group II $(4.288 \pm 0.61, \mathrm{p}<0.001)$.

In Group I (Hypothyroid), there were significant correlation of BMI, S TotalCholesterol, S HDL-Cholesterol, S LDLCholesterol, $\mathrm{S}$ triglycerides and $\mathrm{S}$ creatinine with serum TSH level. However, in Group II (Euthyroid), only LDL cholesterol had significant correlation with TSH level (Table VA). No significant correlation was found of different variables with serum FT4 level in both groups separately. In Group I (Hypothyroid), there were significant positive correlation of BMI and TSH with serum creatinine. In Group II (Euthyroid) only LDL cholesterol had significant positive correlation with serum creatinine (Table VB). 
Table III: Fasting lipid profile of the study subjects

\begin{tabular}{lccc}
\hline Variables & $\begin{array}{c}\text { Group I } \\
\text { Hypothyroid } \\
(\mathrm{n}=80)\end{array}$ & $\begin{array}{c}\text { Group II } \\
\text { Euthyroid } \\
(\mathrm{n}=31)\end{array}$ & \\
\multicolumn{4}{c}{ Mean $\pm \mathrm{SD} /$ Median (Range) } \\
Mean \pm SD/Median & (Range) \\
\hline S. Total-C(mg/dl) & $235.3 \pm 47.92$ & $143.8 \pm 15.03$ & $0.001 \mathrm{a}$ \\
S. Total-C(mg/dl) & $44.48 \pm 9.2$ & $49.35 \pm 4.08$ & $0.005 \mathrm{a}$ \\
S. LDL-C(mg/dl) & $139.7 \pm 45.55$ & $86.29 \pm 13.76$ & $0.001 \mathrm{a}$ \\
S. Triacylgylycerol & $200.0 \pm(110-320)$ & $120.0 \pm(60-30)$ & $0.001 \mathrm{~b}$ \\
\hline
\end{tabular}

a Using Student t test

b Mann Whitney U test

S. Total- $\mathrm{C}=$ Serum total cholesterol

S. HDL-C $=$ Serum High density lipoprotein cholesterol

S. LDL-C $=$ Serum Low density lipoprotein cholesterol

Table IV: Renal function of the study subjects

\begin{tabular}{lccl}
\hline Variables & $\begin{array}{c}\text { Group I } \\
\text { Hypothyroid } \\
(\mathrm{n}=80) \\
\text { Mean } \pm \text { SD }\end{array}$ & $\begin{array}{c}\text { Group II } \\
\text { Euthyroid } \\
(\mathrm{n}=31) \\
\text { Mean } \pm \text { SD }\end{array}$ & $\mathrm{p}$ \\
\hline $\begin{array}{l}\text { Serum creatinine } \\
(\mathrm{mg} / \mathrm{dL}) \text { Total }\end{array}$ & $1.447 \pm 0.43$ & $1.02 \pm 0.2$ & 0.001 \\
Male & $1.46 \pm 0.30$ & $0.98 \pm 0.09$ & 0.001 \\
Famele & $1.36 \pm 0.49$ & $1.08 \pm 0.26$ & 0.064 \\
eGFR(ml/min) & $70.3 \pm 14.2$ & $98.9 \pm 18.5$ & 0.011 \\
Serum uric acid & $6.012 \pm 1.37$ & $4.684 \pm 0.64$ & 0.001 \\
(mg/dL)Total & & & \\
Male & $5.854 \pm 1.27$ & $5.08 \pm 0.67$ & 0.050 \\
Famele & $6.17 \pm 1.48$ & $4.288 \pm 0.61$ & 0.001 \\
\hline
\end{tabular}

-Using Student $\mathrm{t}$ test

-eGFR, Estimated glomerular filtration rate $(\mathrm{ml} / \mathrm{min} / 1.73 \mathrm{~m} 2)=186.3 \mathrm{x}$

$\mathrm{S}$ creatinine $(\mathrm{mg} / \mathrm{dl})-1.154$

$\mathrm{x}$ age- 0.203 [female $\mathrm{x}$ 0.74]

Table VA: Correlation of different variables with serum TSH level.

\begin{tabular}{lllccc}
\hline & Variables & \multicolumn{2}{c}{$\begin{array}{c}\text { Group I } \\
\text { Hyp othyroid } \\
(\mathrm{n}=80)\end{array}$} & \multicolumn{2}{c}{$\begin{array}{c}\text { Group II } \\
\text { Euthyroid } \\
(\mathrm{n}=31)\end{array}$} \\
& & \multicolumn{1}{c}{$\mathrm{r}$} & $\mathrm{p}$ value & $\mathrm{r}$ & $\mathrm{p}$ value \\
\hline \multirow{4}{*}{ TSH } & Age & 0.1930 & 0.086 & 0.1767 & 0.350 \\
& BMI & 0.2216 & 0.048 & 0.1856 & 0.326 \\
& Total cholesterol & 0.3266 & 0.003 & -0.0233 & 0.903 \\
& HDL cholesterol & -0.3285 & 0.003 & -0.0023 & 0.991 \\
& LDL cholesterol & 0.2416 & 0.031 & -0.4404 & 0.015 \\
& Triglycerides & 0.4388 & 0.001 & 0.2550 & 0.174 \\
& Serum creatinine & 0.5870 & 0.001 & -0.1861 & 0.325 \\
\hline
\end{tabular}

Table VB: Correlation of different variables with serum creatinine level.

\begin{tabular}{|c|c|c|c|c|c|}
\hline & \multirow{3}{*}{ Variables } & \multicolumn{2}{|c|}{ Group I } & \multicolumn{2}{|c|}{ Group II } \\
\hline & & & nyroid & ${ }_{\mathrm{P}}$ Euth & \\
\hline & & $(\mathrm{n}=80)$ & $p$ value & $(\mathrm{n}=31)$ & $\mathrm{p}$ value \\
\hline \multirow{8}{*}{$\begin{array}{l}\text { Serum } \\
\text { C reatinine }\end{array}$} & Age & 0.1764 & 0.118 & 0.0095 & 0.960 \\
\hline & BMI & 0.3362 & 0.002 & -0.0940 & 0.615 \\
\hline & $\mathrm{FT}_{4}$ & -0.1329 & 0.240 & 0.0794 & 0.677 \\
\hline & TSH & 0.5870 & 0.001 & -0.1861 & 0.325 \\
\hline & Total cholesterol & -0.0952 & 0.401 & 0.1002 & 0.592 \\
\hline & HDL cholesterol & -0.0628 & 0.580 & 0.0510 & 0.785 \\
\hline & LDL cholesterol & -0.0140 & 0.902 & 0.3895 & 0.030 \\
\hline & Triglycerides & -0.0544 & 0.632 & 0.1217 & 0.514 \\
\hline
\end{tabular}

\section{Discussion}

This study was carried out with an objective to evaluate whether hypothyroidism is associated with dyslipidimia and impaired renal function and also to estimate the lipid profile, assess renal function and determine association of dyslipidemia and impaired renal function with hypothyroidism.

In this current study, the mean serum creatinine was significantly $(p<0.001)$ higher in Group I than that of Group II. These findings are in agreement with that of Khan [7] and Castro et al. [8]. In this study no correlation of different variables with serum FT4 level were found in both groups. This is in contrast to Khan, who demonstrated significant correlation of total cholesterol and LDL cholesterol with FT4 in hypothyroid subjects [7]. There were significant positive correlation of different variables with serum TSH level were found in Group I (Hypothyroid); which were with BMI $(\mathrm{r}=0.2216, \mathrm{p}=0.048)$, with total cholesterol $(\mathrm{r}=0.3266, \mathrm{p}=0.003)$, with LDL cholesterol $(\mathrm{r}=0.2416, \mathrm{p}=0.031)$, and with triglycerides $(\mathrm{r}=0.4388, \quad \mathrm{p}=0.001) ; \quad$ and with serum creatinine $(r=0.5870, p=0.001)$ and HDL cholesterol $(r=-0.3285, \quad p=0.003)$ had significant negative correlation. However in Group II (Euthyroid) LDL cholesterol $(\mathrm{r}=$ $0.4404, p=0.015)$ had significant negative 
correlation. Khan although demonstrated similar correlation of total cholesterol, LDL cholesterol in hypothyroid subjects, but could not find any correlation with HDL cholesterol and TG levels [7]. There were significant positive correlation were found of BMI $(r=0.3362, p=0.002)$ and TSH $\quad(r=0.5870, \quad p=0.001)$ with serum creatinine in Group I (Hypothyroid) and in Group II (Euthyroid) LDL cholesterol had significant positive correlation $(r=0.3895$, $\mathrm{p}=0.030$ ) and other had no correlation in both groups. However, previous study by Khan did not find similar correlation of TSH level with serum creatinine [7]. Mooraki et al. observed that the serum creatinine level reflects the balance between creatinine generation and excretion [5]. While hyperthyroidism can cause hyperfiltration in the kidneys along with a hyperdynamic physiology, moderate to severe hypothyroidism and myxedema can result in the impairment of GFR. A significant correlation between thyroid function and purine nucleotide metabolism has been established in hypothyroidism. Giordano et al. studied 28 patients with primary hypothyroidism and found a significant increase in the incidence of both hyperuricaemia and gout in the hypothyroid patients [6]. Erickson et al. prospectively evaluated 54 patients with a documented gouty arthritis for the presence of hypothyroidism [9]. The prevalence of hypothyroidism was significantly higher in patients with gouty arthritis. Overall, $15 \%$ of these patients, $25 \%$ of women and $12 \%$ of men, had hypothyroidism. These rates were 2.5-fold greater in women and sixfold greater in men than found in the controls.

Despite its absence from standard reference texts, there are several reports relating elevated serum creatinine levels to the uncomplicated hypothyroid state [4]. Giordano et al. evaluated the possible interrelationship between purine nucleotide metabolism and thyroid endocrine disorders, in particular primary hypothyroidism by examining the data in the literature and comparing this with the data observed in a case study [6]. In the literature, while the correlation between hypothyroidism is well established. The study, even if based on a limited number of cases, showed a high prevalence of hyperuricemia in hypothyroid patients, 33.3\%, which is substantially in accordance with the values reported by others. This finding is particularly relevant when compared with the prevalence, ranging from 2 to $10 \%$, in the general population. Moreover, our study showed that hyperuricemia in hypothyroidism is associated with increased serum creatinine and decreased creatinine clearance. This fact suggests that hypothyroid hyperuricemia is secondary to a reduction in renal plasma flow and glomerular filtration, already well demonstrated in thyroid hormone deficiency syndromes.

The finding of a connection between gender and hypothyroid hyperuricemia seem to be important all the same. The data in literatures indicate that hypothyroid hyperuricemia shows the same prevalence in both sexes, while it is known that hyperuricemia and gout are strongly associated with the male sex. The same prevalence of hypothyroid hyperuricemia in both sexes can be explained as follows: hypothyroidism is more frequent in females; hypothyroid hyperuricemia is due to a reduction in renal plasma flow and glomerular filtration secondary to thyroid hormone deficiency.

The limitations of the study were: a) Sample size was small. Larger sample size could give a better and more acceptable result. b) The number of control subjects fewer than the number of cases. It would have been better if more controls could be added. The above limitations were due constraints of time and funds, which should be overcome in future studies.

In conclusion, hypothyroidism is associated with increased serum total cholesterol, increased 
HS Chaudhury, KK Raihan, MN Uddin, SM Ansari, et al

LDL cholesterol, increased serum triacylglycerol and decreased serum HDL cholesterol levels. Hypothyroidism is associated with impaired renal function. Therefore, patients presenting with these biochemical abnormalities are recommended to be investigated for hypothyrodism and vice versa. As our sample size was small and duration of study was limited, another study with larger sample size and longer duration is also recommended.

\section{References:}

1. Unicef. National Survey on Iodine Deficiency Disorders and Universal salt Iodization in Bangladesh 2004-5, 2007, Unicef, Dhaka.

2. Mason RL, Hunt HM, Hurxthal L. Blood cholesterol values in hyperthyroidism and hypothyroidism. N Engl J Med, 1930;203:12731278.

3. Pearce EN. Hypothyroidism and dyslipidemia: modern concepts and approaches. Curr Cordial Rep, 2004;6(6): 451-456.
4. Kreisman SH \& Hennessey JV. Consistent reversible elevations of serum creatinine levels in severe hypothyroidism. Arch Intern Med, 1999;159(1):79-82.

5. Mooraki A, Brounband B, Neekdost F, Amirmokri P \& Bastani B. Reversible acute renal failure associated with hypothyroidism: Report of four cases with a brief review of literature. Nephrology, 2003;8(1):57-60.

6. Giordano N, Santacroce C, Mattii G, Geraci S, Amendola A, Gennari C. Hyperuricemia and gout in thyroid endocrine disorders. Clinical and Experimental Rheumatology, 2001;19:661-665.

7. Khan AH. Lipid profile and renal function status of hypothyroid patients. MD (Thesis), BSMMU, 2005.

8. Castro AVB de, Bononi AP, Aragon F, Padovani CR, Nogueira CR, Mazeto GM \& Pimenta. Clinical and laboratory evaluation of hyperlipemia and hypothyroid patients. Arq Bras Cardiol, 2001;76(2):119-126. 